\title{
STP Strategy on Guidance and Counseling Services Students in Elementary School
}

\author{
Irmawati Duko Ishak \\ Faculty of Teacher Training and \\ Education \\ Universitas Muhamadiyah Gorontalo \\ Gorontalo, Indonesia \\ irmawatiishak@gmail.com
}

\begin{abstract}
Guidance and Counseling Program in Primary Schools is a component of the education system. Guidance and counseling personnel are supervising teachers whose positions are also the same as other subject teachers. In the field of elementary schools implementing guidance and counseling is classroom teachers. The principle of guidance and counseling is to serve all students meaning that it does not only serve children who are facing problems or who are in need of help. STP or Segmenting, Targeting, and Positioning are strategic steps taken in marketing or marketing activities. Positioning is a differentiation created by guidance and counseling teachers or Class Teachers in approaching mentoring to students. Positioning by the teacher is done so that the teacher's image is formed like the student's expectations.
\end{abstract}

Keywords - counseling guidance, segmenting, targeting, positioning

\section{INTRODUCTION}

Schools as educational institutions have an important role in the personal formation of students, both as individuals and as members of the community. In this objective, the School is expected to have well-integrated components, one of the components in question is Guidance and Counseling.

Law No. 20 of 2003 concerning the National Education System listed National education aims to develop the potential of learners to be faithful and fearful people of God Almighty, knowledgeable, capable of being creative, independent and making it a democratic and responsible citizen. This means that achieving quality human resources Indonesian education not only prioritizes the development of aspects of student knowledge but also personal development and the formation of independent students' morals. The implementation of the goal of the education system is that schools facilitate the optimal personal development of students through Guidance and Counseling.

Guidance and Counseling is a school component that aims to help students 'personal development, social life, and student learning activities and help solve students' problems in school. The root of the problem of school education is the problem of morality and exemplary. Evidence of this situation is the number of criminal acts, drug abuse, student fights, criminal acts, and school brawls. Most of the perpetrators of crime and immorality are students. This criminal act was even carried out by students in elementary school [1]. So the hypothesis is that the education process has not succeeded in building students' personalities. So that it needs strong foundations for the development of personality, morals, attitudes, values, social, and potential students that are all done since elementary school.
Elementary School seeks to develop a concept of balanced education that not only leads students to the achievement of academic intelligence but also ensures the achievement of healthy and productive self-development. Students are individuals who are in the process of developing or becoming (becoming) towards maturity that requires structured guidance [2]. the position of guidance and counseling in the education system in Indonesia is contained in Law No. 20 of 2003 concerning the National Education System, while matters relating to basic education where elementary schools are included are specifically discussed in PP No. 28/1999 concerning basic education chapter X. In article 25 paragraph I, in the PP it is said that 1) guidance is assistance provided to students in order to find a personal, know the environment and plan for the future, 2) guidance is given by the supervising teacher.

Teacher and Lecturer Law No. 14 of 2005 in Article 1 Paragraph 1 explained that the teacher is a professional educator with the main task of educating, teaching, guiding, directing, training, evaluating, and evaluating students in early childhood education, formal education pathways, basic education, and secondary education. Having an academic qualification equivalent to $\mathrm{S}-1$, having competence: pedagogic, personality, social, and professional. This law states that class teachers are considered capable as well as being teachers of counseling guidance even though they do not have the education and guidance counseling background.

Based on the interview data of the authors of the classroom teachers in five elementary schools in the Gorontalo district, found a process of class teacher guidance to students in elementary schools, among others, classroom teachers experienced difficulties in instilling learning interest, overcoming learning interest problems, and handling learning difficulties in students. Teachers tend to only teach material according to the curriculum in all subjects. In addition, the absence of a mentoring teacher with a background in counseling education in elementary schools adds to the workload of the classroom teacher making the process of guidance and counseling still carried out as is and only limited to waiting for the problems that arise. This makes the implementation of guidance and counseling to be not optimal.

The implementation of guidance and counseling services has not been fully implemented, because guidance and counseling services are provided for all students, meaning that the service is global or comprehensive, ie for those who have problems or who do not have problems. The implementation of counseling and guidance services is global, meaning that the implementation of Guidance and 
Counseling services is given to all students without exception, besides that student are forced to understand and interpret the importance of the implementation of guidance and counseling services themselves without the support of systematic programs that make students understand the role from the Guidance and Counseling program.

This condition illustrates the difficulty of the teacher in detecting student problems, therefore the teacher also has difficulty in making efforts to prevent any problems. many teachers have not been able to be in line to carry out teaching and learning activities while also providing guidance and counseling to students. in this case, every time they find a problem, the teacher shifts the problem more to the headmaster or vice principal of student affairs. the challenge for the next teacher is that the role and responsibility of the teacher in the future will be more complex, demanding that the teacher be able to perform various enhancements and adjustments to his professional abilities. In addition to the teacher being able to deliver material in a professional manner, able to recognize the needs of students in learning and able to provide tutoring to students in need [3].

Based on this condition, a strategy is needed to facilitate the teacher in detecting each student's problem so that the counseling guidance process becomes part of the system of learning and teaching needs for teachers and students in the classroom in elementary school.

\section{METHOD}

The purpose of this study was to expand and apply the concept of marketing strategies, namely STP strategy on guidance and counseling services in elementary schools. The research method used is analytical descriptive with qualitative methods describing or giving an overview of the object under study through data or samples that have been collected in the form of qualitative data from reviews of data and literature that are relevant to the case that is the subject of discussion [4].

\section{RESULT AND DISCUSSION}

\section{A. Guidance and Counseling Services in Primary Schools}

Guidance and Counseling Program in Primary Schools is a component of the education system in schools meaning that Guidance and Counseling have the same position as other teaching activities. Guidance and Counseling Personnel are supervising teachers whose positions are also the same as other subject teachers. In elementary schools implementing Guidance and Counseling is classroom teachers. Guidance and counseling status in elementary school according to Prayitno stated in the following two main points [5]:

1. Guidance and counseling activities in elementary schools are one component in the standards of classroom teacher work performance.

2. Guidance and counseling activities must be carried out by class teachers for all students in the class they are responsible for.

Students in elementary schools are students aged 6 to 13 years. Where at this age elementary students are undergoing a developmental stage for readiness to continue life. In this development process there are often obstacles and problems, therefore at this age, they still depend on others, especially
Parents and Teachers. Guidance and counseling services in elementary school not only aim to prepare students to go to the next level of education while specifically aiming to help students fulfill development tasks that include personal, social, educational, and career aspects in accordance with environmental demands.

\section{B. Analysis of STP Strategy (Segmenting, Targeting, and Positioning)}

STP is meaning Segmenting, Targeting, and Positioning are strategic steps taken in marketing or marketing activities. Namely, in marketing strategies, this strategy is carried out to focus the customers they want to go. This strategy starts with the segmenting process, then continues with the target selection stage and then determines the position or image of the company. In business and nonprofit organizations, the analogy of STP analysis is the process by which organizations focus on what segments or who they want to serve [6]. According to Tjiptono, the main purpose of market segmenting, targeting, and positioning is to place a product or brand in the minds of consumers so that the product or brand has a sustainable feature or competitive advantage [7].

Every buyer in the market has different desires, resources, location, and the attitude in buying. In providing satisfaction to consumer desires, companies need to group buyers based on their needs and desires. By segmenting the market, the company divides the market into smaller segments that can be achieved more efficiently and effectively with products and services that match the unique needs of buyers. Segmenting has an important role in a company. According to Kotler, segmenting has an important role for several reasons: first, segmenting allows companies to focus more on allocating resources [8]. By dividing the market into segments will provide an overview for the company to determine which segment will be served. In addition, segmenting allows companies to get a clearer picture of the competition map and determine the company's market position.

The second element of marketing strategy is targeting, targeting is the process of selecting the right target for products and services from the company [9]. After previously mapping, the company really knows the potential of the market segment that will be the target of the company.

Positioning is defined as a strategy to win and master the customer's mind through the products offered. Positioning is also defined as an effort to build and gain customer trust. Positioning is the node of strategy. Michael Porter's strategy is to produce a unique and valuable position for customers [10].

\section{STP Strategy in Perspective of Guidance and Counseling Services}

Basically, every goal has a way to arrive at the expected results. A strategy is a series of activities carried out to achieve certain goals. Strategy according to the Popular Scientific Dictionary is a strategy to achieve something. In business science, Strategy is a unified, broad and integrated plan that connects the strategic advantages of the Company with environmental challenges and which is designed to ensure that the main objectives of a company or institution can be achieved through proper implementation by the company[11]. 
Based on this, the STP strategy as a strategy used in the company can be adopted and used as a strategy in guidance and counseling services. STP analysis as part of a strategy that makes it easy for companies to understand customers and shape customer loyalty will make it easier for companies to take the hearts of customers. Then this analysis can also be used to provide convenience for teachers to better understand students even though students have various kinds of characters and differences. This strategy will provide facilities for Guidance and Counseling teachers and classroom teachers in elementary schools in conducting Guidance and Counseling services.

\section{Implementation of the STP Strategy on Counseling Guidance in Primary Schools}

Guidance and counseling in elementary schools must be able to provide services for all students. In this service, regardless of age, gender, religion, ethnicity, and social and economic status of students. The principle of guidance and counseling is to serve all students meaning that it does not only serve children who are facing problems or who are in need of help. While students who are considered not facing problems are not provided with guidance services. The condition of the school is that many teachers do the omission of students and view that children who are not problematic do not need help or the services of smart children can solve their own problems.

Guidance and counseling are closely related to matters relating to the psychological or mental state of students so that guidance and counseling services at schools must pay attention to the psychological and social conditions of students. Guidance and counseling services are an integral part of efforts to improve the quality of education and personal development of students who study in schools so that strategies or methods are needed as a solution so that the service of guidance and counseling is easy to do by the teacher and does not concern the psychological state of students, the STP strategy can be alternative solutions to apply.

The implementation of the STP strategy in Counseling Guidance in Primary Schools is carried out in three steps, namely Segmenting, Targeting and Positioning. The first step is as follows:

\section{1) Segmenting Primary School Students}

Segmenting student groups is identifying and forming groups of students based on student character. By segmenting students, the teacher will be able to determine and compare the conditions of each student and will be able to make adjustments to students or learning programs based on the condition of the student. There are three stages that must be carried out in segmenting student groups are [13]:

\section{- Survey Phase}

The Survey Stage is the initial data acquisition stage for exploration through forming focus groups or by interviewing the stakeholders to obtain information about the target's daily motivation, attitudes, and behavior. the data obtained at this stage will lead to the group where the target will be formed.

\section{- Analysis Phase}

The analysis phase is the stage of applying factor analysis of information that has been obtained through the initial data survey. Analysis can be done by applying factor analysis to examine which variables are highly correlated and then apply group analysis to create or know target groups that have significantly different characteristics.

\section{- Formation Phase}

The formation phase is a stage to identify the profile of each group formed. This will identify the differences in each group based on attitudes, behavior, learning abilities and so on. Each target segment can be named based on its dominance properties.

The presentation of the theory in market segmentation shows how the segmenting process can also be carried out on guidance and counseling services, where the intended segmentation target is students, while the stakeholders involved in the initial interview or data collection activities are parents and students themselves.

\section{2) Targeting}

The next step is targeting or determining the target group, which means that the target group is one or more groups of students who need to be targeted for specific and intense guidance. For character formation, a target group is a group that has a low character, as a target group, this group becomes the target of character formation, this group coaching needs to be done intensely and other special strategy steps.

\section{3) Positioning}

The next step in this strategy is positioning. Positioning in business is a strategy that seeks to create unique differentiation in the minds of target customers so that images or products that are superior to competitors' brands or products are formed. Positioning is how a product in the eyes of consumers distinguishes it from competing products [14]. So in guidance and positioning is a differentiation created by the teacher of guidance and counseling or class teacher in approaching guidance to students. positioning by the teacher is done so that the teacher's image is formed like the student's expectations. In communicating the positioning of a product the company must pay attention to the factors below, namely [15]:

- Be creative means that companies must be creative to steal the attention of the target.

- $\quad$ Simplicity means that the communication delivered must be as simple and clear as possible.

- Consistent yet flexible means to be consistent and see the conditions of the target.

- Own, dominate, protect the point is the communication that is done must have one or more powerful words in the mind of the target.

User's language means that communicating positioning must use the target language.

\section{CONCLUSION}

Associated with guidance and counseling, the above factors must be carried out by the teacher in the activities of guidance and counseling services that the teacher must be creative always innovate in service activities for students, the teacher must also use simple communication and clear language that is easy to understand in moving student's heart. 
The teacher must also be consistent in providing services to students who are in need, more intense to students who have problems.

In addition, the teacher must have interesting words for students so that they can easily move students so that students do something not because of coercion. The teacher must also listen to students more and use language as students want so that the teacher will always be in the minds of students

\section{REFERENCES}

[1] M.Ilham and Novan Ardy. Educational Psychology Theory and Application in the Learning Process. Yogyakarta: AR-RUZZ Media. 2013 p. 18

[2] S.Yusuf. Guidance and Counseling Program in Schools. Bandung: Rizqi. 2009.

[3] Samisih. the role of class teachers in dealing with learning difficulties of elementary school students through tutoring services in scientific journals, Swara Ganesha partners, issn; 2356 - 3443 vol. 1 no. July 1, 2014.

[4] Sugiyono. Quantitative, Qualitative and R \& D Research Methods. Bandung: Alfabeta, 2009
[5] Rayitno. Guidance on Activities for Supervision of Guidance and Counseling in Schools. Jakarta: Rineka Cipta.1999 Page 55

[6] D.I. Nugroho. Introduction to management for Business and Nonprofit Organizations. Malang: UB Press. 2017.

[7] F.Tjiptono. Service Management Realizes Excellent Service. Yogyakarta: CV Andi Offset, 2012.

[8] K.Philip and Keller, Kevin Lane. Marketing Management, Volume 2, 12th Edition, Jakarta: PT. Index, 2008.

[9] H. Kartajaya. MarkPlus On strategy, 12 years Markplus Travel \& Co. Building Company strategy. Jakarta: Gramedia Main Library, 2000

[10] H.Kartajaya Hermawan Kartajaya on Positioning. Jakarta: Mizan Pustaka, 2004 Page 15.

[11] P.A. Partanto and M. Dahlan Al Barry, Popular Scientific Dictionary, Surabaya: Arloka, 1994, page. 727.

[12] M.Nganam, et al. Strategic Management Implementation: Policy and Proses.Yogyakarta: Amara Books. 2006 page. 15

[13] M.Nganam, et al. Strategic Management Implementation: Policy and Proses.Yogyakarta: Amara Books. 2006 page. 15

[14] F.Tjiptono. Marketing Strategy III Edition. Jakarta: Andi 2004 page. 109

[15] A. Nopianto, Destina Paningrum, Pengembangan Laboratorium Bisnis Melalui Segmentasi, Targeting dan Positioing, Ekonomi Bisnis \& Kewirausahaan Vol. III, No. 2, Agustus 2014, hal. 70. 